\title{
The Local Environmental, Economic and Social Tragedies of International Interventions on Community Based Forest Management for Global Environmental Conservation: A Critical Evaluation
}

\author{
Bhubaneswor Dhakal \\ Support for Development, Christchurch, New Zealand \\ Email: Bhubaneswordhakal@gmail.com
}

Received October $16^{\text {th }}$, 2013; revised November 21 $1^{\text {st }}$ 2013; accepted December $19^{\text {th }}, 2013$

\begin{abstract}
Copyright (C) 2014 Bhubaneswor Dhakal. This is an open access article distributed under the Creative Commons Attribution License, which permits unrestricted use, distribution, and reproduction in any medium, provided the original work is properly cited. In accordance of the Creative Commons Attribution License all Copyrights (C) 2014 are reserved for SCIRP and the owner of the intellectual property Bhubaneswor Dhakal. All Copyright @ 2014 are guarded by law and by SCIRP as a guardian.
\end{abstract}

This study reviewed the policies and outcomes of international support for forest management in Nepal and answered whether international support on forest management in developing countries resulted in positive socioeconomic and environmental outcomes at local communities. The evaluation is based on the socio-ecological theory and synergies-tradeoff model of forestry ecosystems goods and services. The study shows that the international interventions influenced national policies and community forestry practices, which contributed to the remarkable increase of forest stock. The new forestry institutions increased timber product supplies to urban users and contributed to offsetting of greenhouse gas emission of affluent societies in overseas. However, the intervention spoiled centuries of old forestry practices, which had contributed to the evolvement of socio-ecological condition, sustained local economy and environment systems. The new forestry institutions and practices locked local opportunities of multipurpose uses of forest, worsened water yield and local knowledge, and hampered local economic activities. Consequently they affected habitat diversities for forest based species, and forest resource supplies for sustaining agrobiodiversities and local food security. In reality the interventions increased benefit to distant users (urban users in the country and affluent societies in overseas) and further marginalized local communities and particularly socially disadvantaged people. The paper shows that the international forestry policies and supports are technically wrong or poorly based on science which is against their promise of providing better technical supports and benefiting local communities in developing countries. It argues that the interventions created many complexities in forestry institutions and practices which require too costly endeavor to change and address the local socioeconomic and environmental problems. The paper has explained the root cause of the international policy problem on many schools of thought.

Keywords: Socio-Ecological Systems; Community Abuse; Synergies-Tradeoff Model; Kaleidoscopic Case

\section{Introduction}

Forestry is a common property in many developing countries and particularly in mountain regions. The resource has multiple, competing uses for environmental conservation and human wellbeing (Karsenty \& Ongolo, 2011). Most environmental policy analysts argued that the forests are poorly and inefficiently managed, which has exacerbated environmental problems. International policies and supports are believed to improve resource management efficiency, increase local socioeconomic benefits and contribute to global environmental conservation (Douglas \& Simula, 2010). Many policies and field activities have been implemented at national, regional and international initiation for many years. There is also a counter argument that the forest managed for global benefit can lead tradeoffs outcomes to local communities, affect both communi- ties and ecosystems and worsen the mountain vulnerabilities (Hausler, 1993; Ives \& Messerli, 1989). The argument is based on the fact that social, economic and environmental systems in developing countries are complex, often vulnerable and strongly attached with forestry resources (Jodha, 2001; Ives \& Messerli, 1989). Inappropriate intervention can disestablish existing systems and make social and environmental problems worse. However, critical problems of international interventions particularly on the management of common property forest in mountain context are poorly explained and documented in literature.

The aim of the study is to synthesize existing knowledge about international forest policies. Specifically this study reviewed emerging local environmental, economic and social problems associated with international interventions on managing common property forest resources for global environ- 
mental conservation. It means that the focus of the study was on emerging problems of the forest management, which was associated with international interventions. This study was carried out with the assumption that the international forest policies and external supports overlooked local importance of the common property forests and indigenous forestry practices, and exacerbated local problems.

This study is based on opinion and literature review and particularly the case of international interventions for communitybased forest management in Nepal. Information available from desktop literature review and other secondary sources are used to support the arguments and opinions. In addition this study applied theories, intuitive logic, learning from work experience, published material and field research to explain the problems. These approaches are popularly used in the literature particularly in cross-disciplinary issues (Karsenty \& Ongolo, 2011). This study limited explaining the problems of external intervention on the following issues: Biodiversity, water and local knowledge conservation, climate change adaptation, food security, economic development and social abuses.

Regarding structure of this paper, the importance of multipurpose management of the common property forest for mountain rural communities and the model of synergies and tradeoffs of forest ecosystems are described in the two subsequent sections. Other section provides a brief account of history of international interventions on the Nepal's forestry sector. Then the emerging local environmental, economic and social problems are described. The causes of the problems of the interventions are described on different views before concluding the paper.

\section{The Importance of Multipurpose Management of Forests and Evolution of Socio-Ecological Systems}

Nepal, as a mountain country, has a special significance of forestry resources particularly human modified ecosystems. Its land environmentally safe for human settlement and farming uses are distributed in patches. The mountain communities were settled and carried out farming in the environmentally safe lands (a low risk of landslides and malaria). The limits of environmentally safe land resulted in the existence of agricultural land patches inside or adjoining public forests and small-size of private land holdings. The unsafe lands were managed as a common property and used together in forest and pasture production to meet the broader needs of communities and environments. The communities used multiple products and services of the common property to complement private resources and sustain livelihoods (Dhakal et al., 2011; Hobley, 1996). Products and services derived from the joint management complement farmland resources and contribute to sustaining the livelihoods of mountain people with small size of landholdings. Therefore, almost all communities have some areas under common or public forest and many kinds of wild animals in the forests close to human settlement. The multipurpose management and common property systems eased transfer of other resources (e.g. crop and animal genetics and local knowledge) between agroclimatic zones. The forest resources, thus, have been an integral part of agricultural and other socioeconomic systems in the societies.

The multipurpose management system also reduced the wildlife effects on agriculture and provided habitat for many wildlife species. The centuries old community practices of manag- ing the forestry resources for multiple uses have modified natural systems which resulted in the development of social-ecological systems (e.g., forest product based agro-biodiversity and indigenous knowledge) that significantly shape ecosystems in the Nepali mountain landscape today. This land distribution pattern hardly found in most European countries where the land is extensively privatized and used in farming, e.g., 75 per cent of the land area in UK. The interactions of the social and ecological systems have not only determined the provisioning of ecosystem goods and services but also contributed to the development and sustaining of new ecosystems (e.g., wild biodiversity in farm and human modified forest and pasture systems).

Some social groups in the country have a nomadic style of living and others have high dependency on the land resources in managed communal systems. Unlike farmers in western and other societies, the communities used only a small land area to cultivate crops though it was insufficient to feed the families. They practiced cultivating the land once in 5 years or so (Rasul \& Thapa, 2003). They complemented the private resources by forest resources, particularly non-timber products, and sustained their living. The non-timber forest products could reach harvestable size in a short time and be available mostly free throughout the year. That is the fact to have a higher proportion of forest areas and rich biodiversity around their community areas. The critical role of the forestry and farming practices in sustaining environmental resources are hardly recognized in environmental literature. The lands traditionally used under shifting cultivation practices, nomadic systems or managed in common are registered as public forests. These are now excessively controlled by state authorities. The territories of the indigenous people have been used for environmental conservation in national elite and international interests. The communities are squeezed in marginal lands, and forced them to grow crop in environmentally sensitive lands and shorter rotation period. The forest based people are blamed for encroaching on environmentally sensitive land and using forest resources (Rasul \& Thapa, 2003) but the fact of evolving the resource use practices and reasons of current changes in their practices are ignored.

Community forest has a special importance for agricultural and forest biodiversity conservation. According to CBS (2008) endanger wild animals and plant species exist not only in the protected areas in Nepal but in farming and community forest areas. Many birds, wild animals and invertebrates share habitats in both forest and farmlands. Maintaining the biodiversity needs diversity of habitats, which requires diversity in forest condition. Community forests are small in area, average 93 ha per community with most less than 60 ha in size at current conditions (Kanel et al., 2012). The diversity in resource and habitat condition is less likely to be naturally created. Mountain communities were used to practicing coppicing and lopping of forest trees for multipurpose uses. Allowing the practices enhanced habitat diversities for forest species and supplied resources supporting agro-biodiversities. Crops in farming land provided refuge for many wildlife species on the forest edge especially during natural disasters (e.g., forest fires) and feed in scarce seasons.

Nepal is a home to many typical local breeds of cattle, buffalo, sheep, and goats (CBS, 2008), which were fed on the community forest pasture for centuries because of the limited private land resources for feed. In the 1985/86 survey, public 
forest contributed about 70 per cent of livestock feed requirements in the high hills, 39 per cent in the mid hills, 15 per cent in the Terai, and 60 per cent in the Siwaliks region (MPFS, 1988). The share of forest fodder for livestock feed under the current management system, however, has been negligible in most communities. The practices of grazing and tree harvesting for other uses suppressed aggressive weeds and created diversity in the habitat matrix, which enhanced and maintained the diversity of both animal and plant species. The practices, for instance, enhanced the habitat of some bird species and were particularly popular in controlling insects in farm lands, which requires moderately open forest conditions and bushes.

Alpine land is another important common property in the mountainous areas, which occupy over 10 per cent of total land area in Nepal (CBS, 2008). Its vegetation consists of seasonal pasture species and perennial plants, including shrubs, but trees are rare. The resources could be used in the transhumance practice that requires seasonal movement of animals to different agro-climatic zones. Most livestock was managed under the Kharka system (mobile grazing system). Grazing in the forests was rotational, based on seasonal availability of feed on farms and in the forests (Graner, 1997). Transhumance herds grazed alpine pasture during the rainy and autumn seasons and required access to pastureland in warmer places during the cold season. During the winter and spring seasons, those animals also fed on forest-based tree fodder in addition to grazing. The supply of forest fodder was also essential for farmers in other regions when farm fodder ran out, particularly in spring and summer. The practice of livestock grazing and other uses of alpine resources suppressed weeds and other unwanted invasive species (Dhar et al., 1997), which created habitat diversity for wild plant and animal species (Kala, 2004). In addition, seeds of many wild plants get treated and spread through the dung of grazing animal.

The common property resource played a crucial role in developing and sustaining farm crop and animal biodiversity. Sustaining the transhumance practice requires changing places for livestock grazing in different communities and agro-climatic zones. The practice provided opportunities to cross breed high altitude livestock species, which enriched diversity in the gene pool of the livestock population (Kharel et al., 2005). Those animals were placed on and fed in cropping lands during winter for farm fertilization. Traditionally, many varieties of local vegetables, herbs, spices and other food crops and breeds of livestock were sustained on the forest resources and livestock compost. Some of the plant species are chemical fertilizer intolerant (Raut et al., 2012).

Poor rural houses require forest products to complement their private resource and so sustain their livelihood because of possessing insufficient private land resources and a poor level of livelihood assets (Dhakal et al., 2011). Non-timber forest products are the main inputs to leverage their farm economic activities and the means to utilize their spare work time for income generation. Communities used to follow a coppicing system for firewood and a lopping practice for fodder collection under traditional forest management systems that produced considerable amount of daily needed products for the people. The practices had increased the availability of other products (poles and stakes for agricultural uses) and created some open spaces in the forest allowing other non-timber species to grow under the trees (Harrop, 2007).

One problem in disadvantaged Nepali communities is low level of local economic activity that leads to the region being less attractive for development investment. Young people and active labour force hardly live in the communities. Members of rural communities are now bearing huge social and emotional costs (e.g. increasing marriage divorce and mental sickness from family isolation) because of migrating of young people and parents to work in overseas such as the Middle East and Malaysia (Gartaula et al., 2012). The forest resource supported local employment would provide people an opportunity to live with family, provide emotional needs and care, and help communities, which are not possible while working in the overseas. Local employment and income generation opportunities are extremely important to women who socially have less access to and more risks in off-community and overseas employment. Increasing production of non-timber products would many other people including retired and frustrated from jobs who would like to be returned in their communities and engaged in some economic activities.

Through many years of practice and experience, mountain communities have identified several kinds of local resources and their utilization techniques to solve the problems of resource scarcity, health nuisance and natural disaster (Dong et al. 2007). People in disadvantaged communities require, for instance, local forest species that can be used to relieve physical stresses and control incursions of pests and diseases. Much local knowledge and some cultural features are based on forest resources and mostly on non-timber forest products. The resources, skills and services of traditional knowledge are more valuable for rural women and other poor people who have poor access to or affordability of modern services (Rokaya et al., 2010). The information must be continuously updated, which can often be costly to provide from a research approach for local decision making. It is also too costly to document locally valuable knowledge and teach it to people. The knowledge generally passes by word of mouth from people who observe or practice the activity. Availability of the resources had made it possible to pass local knowledge and skills from the older generation to a younger one by word of mouth and actual practice. Farmers and others working in alpine regions were sources of information and suppliers of herbal medicines for rural community, which was important particularly for people in disadvantaged and remote communities, and natural disaster conditions (Dong et al., 2007).

The above discussions show that the centuries old community practices of managing forests for multiple purposes resulted in the development and sustaining resources and environmental systems adaptable to the biophysical and socioeconomic conditions. According to Folke et al. (2003) the modified system can be termed as the coupled social-ecological system and used as an analytical framework to evaluate provisioning of natural, socioeconomic and cultural products and services regulated and sustained by a system created by interactions of biophysical and social phenomena. The framework is considered relevant to evaluate how localized socioeconomic and environmental systems are impacted by the international interventions on community forest management. The synergies and tradeoffs model of forestry product and services is included to clarify biophysical phenomena.

\section{The Science of Synergies and Tradeoffs of Forest Ecosystem Services}

Experimental based studies show that ecosystems services of forest vary with management models (Phelps et al., 2012; 
Kapos et al., 2012; Strassburg et al., 2012; Amato et al., 2011; Thompson et al., 2009; Bruijnzeel, 2004). Following the theories the synergies and tradeoffs of some ecosystems services under different levels of tree canopy cover in a hypothetical community forest can be illustrated as in Figure 1. The figure indicates that increasing forest canopy conver increases carbon storage (climate change mitigation service) and reduces soil erosion (enhance soil conservation service) upto certail level. It enhances biodiversity conservation services in some extent and then reduces. However, the increasing forest cover reduce downstrem flow (water service). Soil erosion level might also be increased again in some level at extreem canopy cover condition of the tree though it is not explicit in the graph. The synergies and tradeoffs model implies that many ecosystems services of forest would be provisioned at higher level under moderate than extreme canopy cover condition. The moderate canopy condition provides a room to produce a significant amount of products valuable in supporting economies in communities and livelihood of local people.

\section{History and Problems of External Intervention on Mountain Forest Management}

Most forests in the mountains were traditionally managed under a community system with multiple uses for the broader needs of communities. Substantial forest degradation happened around district and regional headquarters following the political system change 1951 due to increasing of public construction and town development activities (Hobley, 1996). Coincidentally, in the early 1970s extreme rainfall occurred causing devastating landslides in Nepal and flooding in Bangladesh ${ }^{1}$. International agencies blamed on local farmers for the deforestation, landslides and flooding problems and started interventions on the forest and pasture resource management. One of the reasons to increase their interventions on the forest management since 1980 s is to make contribution on global climate change mitigation (Hausler, 1993). Table 1 shows the key dates and international agencies influencing common property forest management in Nepal. Critical details of international interventions are presented by Hobley (1996), Hausler (1993) and Ives and Messerli (1989). The international pressurized the government to change the indigenous forest management and using practices (Hobley, 1996; Ives \& Messerli, 1989). The aid agencies con-

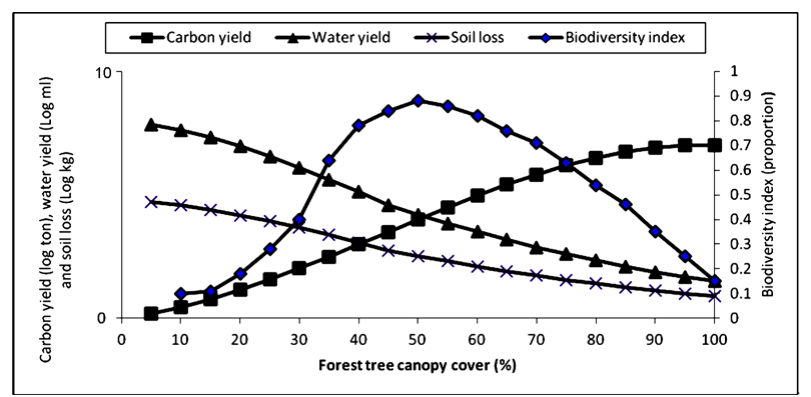

Figure 1.

A general model of synergies and tradeoffs of some ecosystems services under different levels of tree canopy cover in a hypothetical community forest.

$\overline{{ }^{1} \text { According to the UN Climate Change Report (2007), the global rainfall }}$ pattern remarkably changed from this time and Australia also experienced devastating floods in this period. sidered that the technical, financial and institutional capacities of the Nepal government were very poor to manage forests appropriately and international support on the issues, including policy advocacy, would conserve forest and halt environmental problems.

The international agencies misinterpreted the mountain resource management practices and problems, and carried out interventions without due consideration on social, economic and other environmental consequences from their interventions. According to the Forestry Sector Master Plan "[T]he main causes of forest degradation are overcutting of wood for fuel and heavy lopping of trees for fodder” (MPFS, 1988: p. 31). The plan was developed under their strict technical guidance and support of the international agencies (Hobley, 1996; Hausler, 1993). The plan discouraged the use of local forest practices and non-timber forest products, which were practices of hundreds of years to meet the broader needs of communities (MPFS, 1988). The data and estimation processes were manipulated which resulted over exaggeration of demand and underestimation of supply of timber (Hrabovszky \& Miyan, 1987). It was planned, funded and practiced for "reducing and controlling livestock numbers” of mountain farmers (MPFS, 1988 p. 148) even though livestock farming was the engine and inspiration to sustain farming systems and maintain economic and environmental vitality in the mountain region (Hausler, 1993). The plan focused forest management to increase timber and firewood supplies to urban users and industries and gave little value to increased non-timber forest products to meet local community demands (Dhakal, 2011; MPFS, 1988). The agencies advised specially to introduce industrial model of forest management in the name of providing technical support of international experts for improve management of the community based forests.

Though the donor agencies implemented the Master Plan by establishing their own organizations (often called "forestry development project") parallel to government bodies (Edmonds, 2003), under expatriates' leadership or advice, they played wrong role model. They ignored local problems while implementing the Master Plan. Government agencies considered themselves weak in technical capacity for institutional building so followed the forest development model of the donor agencies in other districts with no direct involvement of the international agencies. They relied on the assumption that donors' working model was superior.

The protected areas expanded dramatically as IUCN and WWF intervened in the protected area programme including the preparation of conservation planning (Basnet, 2003). The area of Nepal occupied by protected areas has increased now over 21 per cent (CBS, 2011). Until the 1970s, the national parks and wildlife reserves had occupied only three per cent of the national land area and established in the forests and other community areas convenient for recreational use by king Shaha families. IUCN intervened the Nepal government's policies to extend protected areas in forest rich regions to meet its global target of increasing protected areas. The aid agencies provided technical advices, financial supports and personal development incentives to motivate decision makers of conservation agencies for expanding the protected areas in poor community areas where local livelihoods were mainly based on the resources of the common forests. Otherwise the expansion would have occurred only in some regions or small areas.

The REDD policy, endorsed in the global climate summit, 


\section{B. DHAKAL}

Table 1.

Key dates and international agencies influenced on forest management in Nepal (Sources: Hausler, 1993; MPFS, 1988; GOA, 2012).

\begin{tabular}{|c|c|c|}
\hline Period & Agency & Action \\
\hline Early 1970s & $\mathrm{xx}$ & Extreme rainfall occurred causing devastating landslides in Nepal and flooding in Bangladesh \\
\hline Early 1976 & $\begin{array}{l}\text { Eckholm from World } \\
\text { Research Institute (WRI) }\end{array}$ & $\begin{array}{l}\text { Warned that Nepali farmers followed wrong farming and forestry practices which were leading towards serious } \\
\text { environmental disasters in Nepal and downstream (Eckholm, 1975). }\end{array}$ \\
\hline 1976 & AUSAID & $\begin{array}{l}\text { Introduced and supported tree plantation, mostly exotic pine species in pasturelands and multipurpose use forests of } \\
\text { poor communities. The government and other aid agencies followed the model to show physical progress of forestry } \\
\text { development. }\end{array}$ \\
\hline 1978 & World Bank & $\begin{array}{l}\text { The World Bank warned internationally that all forests in Nepal would be wiped out within two decades if traditional } \\
\text { forest practices would not halted. The practices would create a severe environmental catastrophe in the country and } \\
\text { downstream. }\end{array}$ \\
\hline $\begin{array}{l}\text { Post } \\
1978-1988\end{array}$ & $\begin{array}{l}\text { AUSAID, The World } \\
\text { Bank, USAID, UK aid, } \\
\text { SDC, FINNIDA, GTZ }\end{array}$ & $\begin{array}{l}\text { Influenced on the government policies of natural resource management by policy dialogues, advocacy and offer of } \\
\text { financial supports. They shifted their technical advices and financial support from integrated rural development to } \\
\text { forest plantation and protection. }\end{array}$ \\
\hline 1982 & $\begin{array}{l}\text { Wyatt-Smith, the British } \\
\text { forestry expatriate }\end{array}$ & $\begin{array}{l}\text { Using a case study warned that mountain farmers kept unsustainable numbers of livestock, exceeding the carrying } \\
\text { capacity of the forest which caused deforestation and accelerated soil erosion in the mountain. }\end{array}$ \\
\hline 1988 & $\begin{array}{l}\text { FINIDDA, Asian } \\
\text { Development Bank and } \\
\text { FAO }\end{array}$ & $\begin{array}{l}\text { Provided technical support and guidance to develop Forestry Sector Master Plan for } 25 \text { years which dictated to } \\
\text { "reduce and control livestock", cease indigenous forestry practices (lopping of tree branches for fodder and firewood) } \\
\text { and increase plantation and timber production to meet urban and industrial needs. The plan was greatly influenced by } \\
\text { the Eckholm (1975), the World Bank (1978) and Wyatt-Smith (1982) reports. }\end{array}$ \\
\hline Post 1988 & IUCN and WWF & Increased influences at policy and implementation levels to expand protected areas and meet their global target \\
\hline 1989-2006 & $\begin{array}{l}\text { World Bank, SDC, DFID, } \\
\text { AUSAID, DANIDA, } \\
\text { GTZ and USAID }\end{array}$ & $\begin{array}{l}\text { The agencies used provided financial and technical support and hastily carried out forestry conservation activities } \\
\text { (formation of user group assigning forest management responsibility, forestry plantation and protection) following } \\
\text { the concept of the Forestry Master Plan (1988). Local socioeconomic and other environmental effect cared little. }\end{array}$ \\
\hline 1992 & Earth Submit & $\begin{array}{l}\text { The government introduced the Forest Amendment Act in } 1998 \text { and a mandatory forest inventory was introduced to } \\
\text { regulate forest uses as directed by "Sustainable Forestry" in Agenda } 21 \text { and contribute to global climate change } \\
\text { mitigation. The policy has dictated compulsory forest inventories and limited forest harvesting to } 50 \% \text { of the mean } \\
\text { annual increment of forest. }\end{array}$ \\
\hline 2007 & Climate Submit Bali & $\begin{array}{l}\text { Introduced Reduced Emission from Deforestation and Forest Degradation (REDD) policy and the World Bank } \\
\text { selected Nepal for REDD policy experimentation. }\end{array}$ \\
\hline After 2007 & $\begin{array}{l}\text { Various funding and } \\
\text { support agencies }\end{array}$ & Introduced many REDD projects and continued funding for protected area expansion in community forests. \\
\hline
\end{tabular}

Bali 2007, is another international intervention in community forest management in Nepal. International agencies were interested in giving continuity to their past businesses of forest expansion and protection in Nepal, and in contributing to the global environmental conservation goal. The main objective of the REDD policy is to reduce the community uses of forest products and enrich the forest carbon stock to offset global greenhouse emissions produced by affluent societies and industries in developed countries. The international agencies would like to restrict local practices of using forest products and manage the resources in an intact natural condition. Table 2 shows the names of the implementing and funding agencies of the REDD projects (GON, 2012). Despite the pilot phase programme it has been implemented in 58 districts out of 75 districts in the country. The REDD experimentations are also done even in very poor and tribal communities (Uprety el at., 2011). It has advised and funded enrichment plantations in open forest spaces to increase forest cover, and thinning, pruning and weeding activities to enrich logs and carbon stocking (Khadka et al., 2012). The REDD funding has been considered as a resource and opportunity to revive slacked international forestry funding particularly for boosting personal development activities and other facilities for forestry professionals.

\section{Local Tragedies of International Interventions}

International agencies played crucial roles to change Nepal's forest management for environmental conservation (Hausler, 1993; Ives \& Merselli, 1989) and brought some physical progresses in mountain forestry landscapes. About 15,000 forest user groups are formed within 20 years and have taken over responsibility of local forest protection (Kanel et al., 2012). Coverage of protected areas increased from 7 percent in 1988 to over 20 percent in 2011. Forestlands are well covered by trees in most cases (FAO, 2010). Bare land areas in the accessible forests are planted in most cases. The wood stock of community forests is increasing on average by 2 cubic meters annually (Kanel et al., 2012). Harvestable sizes of trees have been overstocked and underutilized in many cases (Khanal, 2002). Carbon pool has been enriched (FAO, 2010). Production and availability of timber has been exceeded demand and local availability of firewood has been increased in some extent and communities (Kanel et al., 2012). The user groups are also serving as legal grass root bodies to deal with external agencies or people. Local fund has been generated for forest and other community development by selling of forest products and recently carbon emission reduction service in few groups (Khadka et al., 2012). 


\section{B. DHAKAL}

Table 2.

Current PES schemes in Nepal (Sources: REDD, 2013; GON, 2012).

\begin{tabular}{|c|c|c|c|c|}
\hline S.N. & Implementing agencies and program & Funding agencies & Program districts & Objective \\
\hline 1 & $\begin{array}{l}\text { ICIMOD, FECOFUN and ANSAB } \\
\text { (REDD + payment systems) }\end{array}$ & NORAD & $\begin{array}{l}\text { Dolakha, Gorkha and } \\
\text { Chitawon }\end{array}$ & $\begin{array}{l}\text { Pilot test of REDD payment scheme for forest carbon } \\
\text { offsetting service }\end{array}$ \\
\hline 2 & $\begin{array}{l}\text { WWF, CARE, NTNC and FECOFUN } \\
\text { (Hariyo Ban Program) }\end{array}$ & USAID & Many districts $^{2}$ & REDD scheme for biodiversity conservation in forest \\
\hline 4 & $\begin{array}{l}\text { WWF } \\
\text { (Poverty alleviation REDD+ pilot) }\end{array}$ & WWF and Winrock & $\begin{array}{l}14 \text { districts in mid and } \\
\text { western regions }^{3}\end{array}$ & $\begin{array}{l}\text { REDD scheme for poverty alleviation an biodiversity } \\
\text { conservation in forestry }\end{array}$ \\
\hline 5 & $\begin{array}{l}\text { LFP project of Plan Vivo } \\
\text { (an international NGO) }\end{array}$ & UK & $\begin{array}{l}\text { Mahottari } \\
8 \text { Villages }\end{array}$ & $\begin{array}{l}\text { REDD scheme for forest carbon enhancement and local } \\
\text { livelihoods support }\end{array}$ \\
\hline 6 & $\begin{array}{l}\text { Rupantaran NGO-The Himalayan } \\
\text { Community Carbon Project }\end{array}$ & UK, SDC \& FINIDA & $\begin{array}{l}\text { Dolakha, Bugling Rupandehi } \\
\text { and dang }\end{array}$ & $\begin{array}{l}\text { REDD scheme for enhancing forest and community } \\
\text { ability to adapt to climate change; and reduce livestock } \\
\text { grazing/feeding in forest resources }\end{array}$ \\
\hline 7 & $\begin{array}{l}\text { NIFIN, IWGIA, AIPP and IPICPRE } \\
\text { (Climate Change and REDD } \\
\text { Partnership Program) }\end{array}$ & NORAD & 58 districts & $\begin{array}{l}\text { Awareness creation about REDD benefit to } \\
\text { indigenous people }\end{array}$ \\
\hline 8 & Awareness to collaborative forest users & SNV & Mahottari district & Community capacity building \\
\hline 9 & $\begin{array}{l}\text { Forest Ministry } \\
\text { (Programme for readiness for REDD) }\end{array}$ & World Bank & National level & National REDD capacity building \\
\hline
\end{tabular}

Recently information systems of forestry resources are greatly improved. However, the international interventions have resulted in many environmental, economic and social tragedies at local level. It takes a considerable period to experience both positive and negative impacts of recent international interventions such as Reduced Emission Deforestation and Forest Degradation-plus (REDD). The major tragedies of all the international interventions so far experienced are as follows.

\section{Biodiversity Loss}

Changes in the institutions and management of community forests by external intervention affected both forest and agricultural biodiversity. External agencies brought industrial model of forest management and advised forest users to remove naturally grown non-woody vegetation and shrub species, and replace the area by fast growing trees to enhance log production and carbon stocking. Commencing effect of conservation actions most of forests are covered by tree and other aggressive species regenerated naturally and overstocked in some cases (Shrestha et al., 2010). The suppression of these products created daily need products scarcity of forest users that caused over exploitation understory resources and left barely resources for biodiversity (Shrestha \& McManus, 2008). Decreasing the resources on the forest floor forced wild animals to go into agricultural lands for their feed, which increase their vulnerability. The habitat of common birds providing seed dispersal and pest regulation services are the bushes grown in moderately open forest conditions which have been lost. Declining transhumance systems reduced the weed control service of livestock and farmers that results in the invasion of local aggressive and exotic weeds into alpine pastureland (Kala \& Shrivastava, 2004) which is little studied in Nepal. The species established in open pasture and livestock dung over many hundreds of years may have declined to extinction. Communities have still advised and funded tree planting to fill any open space left in the forest (Karky et al., 2012; Khadka et al., 2012). The diverse forest conditions, including some open spaces (in terms of tree cover) for maintaining forest biodiversity, thus, hardly remain. Biodiversity has been also significantly degraded in reduction of human uses of forest products and services as community used forests converted into protected areas (Christensen \& Heilmann, 2009). Creating a biodiversity healthy regime requires removing and replacing some trees which reduce carbon pool below the baseline level and affect payment in REDD forests. The government also has poor institutional capacity to afford and manage for creating healthy forest state in protected areas and other public forests. In addition, forest officials feel a risk of misusing the forests by communities and elites so resist allowing change on forest management. Therefore, the REDD forestry practices, as funded by the USAID (Table 2), rather contribute to escalating degradation of forest biodiversity evolved in open spaces created by human activities and the reduction of forest resource supplies to support agro-biodiversities.

Change in forest management has also degraded agrobiodiversity. Declining access to forest grazing services has reduced the population of high hill animals such as yak, decreasing 1.8 per cent annually (CBS, 2008). The animal feed in forest pastures for thousands of years, is economically little viable and probably biophysically unfit in stall-feeding management systems. Some of the local breeds of goat and cattle could not survive well in stall feeding. According to CBS (2008), pure breeds of some livestock are extinct (e.g., Siri cattle) and others (e.g., Lulu and Achhame cattle, Lime buffalo, and Lampuchhre and Kage sheep), are threatened to extinction which were sustained and evolved on forest pasture and grazing for hundreds years. Forest conservation practices also reduce livestock mobility and the opportunities for their cross breeding between different geographic regions, and the fertilization of farms scattered

${ }^{2}$ Kanchanpur, Kailali, Banke, Bardiya, Nawalparasi, Chitwan, Bara, Parsa, Rautahat Mustang, Chitwan, Kaski, Tanahu, Manang, Lamjung, and Gorkha.

${ }^{3} 14$ Districts (Rautahat, Bara, Parsa, Makawanpur, Chitwan, Nawalparasi, Rupandehi, Kapilbastu, Dang, Banke, Bardia, Kailali, Kanchanpur and Argakhachi). 
in different geographical areas. Crop varieties suitable in less productive and rain-fed land are disappearing from communities as farm manure production or availability decreased with the restrictions on forest use for livestock production and mobility. The land is either abandoned for cropping or put to other uses because of decreasing farm manure supplies and increasing fertilizer prices (Raut et al., 2012). Loss of vegetable species susceptible to fertilizer is natural in the shortage of farm manure as it happened in England in 1960s (Robinson \& Sutherland, 2002).

\section{Water Problem}

Most rural communities use spring water and experience a shortage during late winter to summer. Communities have experienced declining water flow in spring and stream with increasing forest cover in catchments (Kanel et al., 2012). The management of community forestland is critically important for water recharge service. Scientific studies carried out in different ecological conditions clearly showed that increasing forest cover reduces downstream water flows significantly in low rainfall and summer seasons. There is little evidence that forest cover has any contribution in rainfall except the cloud forest in Latin America (Bruijnzeel, 2004). Government agencies of some developed countries, therefore, discourage forestation in drinking water catchments of scarce water supply areas. However, some influential international agencies (e.g., IUCN and FAO) recommended the Nepal government to enrich forest and attain full cover to increase rainfall and water supply in critically scarce areas and seasons (IUCN, 2006; FAO, 1996).

\section{Local Knowledge and Resources Loss}

The new forest management has affected local knowledge gained in hundreds years of practices. Community knowledge on and indigenous practices of using of forest resources declined under community forestry and protected area programme which reduced access to forest and availability of non-timber forest products (Pandit \& Kumar, 2010). Information about the resources of alpine regions and remote areas decreased when people's opportunities to graze alpine pasture were reduced by being blocked for grazing in warmer belt forest during winter and spring. The growth of many species valuable in sustaining local knowledge is suppressed or lost because restriction on resources uses fosters domination of aggressive plant species (Kala \& Shrivastava, 2004). The decreasing use of local knowledge and skills is making people pay high costs for market goods and services. Market goods and services at affordable prices are often not safe to use, particularly for people in disadvantaged and remote communities. It has been too costly to make them revive of the collapsed local knowledge systems and institutions in the communities. The declining of sources of information and the supply of non-timber forest products (e.g. herbal medicines) for rural communities has, thus, aggravated the vulnerability of poor people, especially women, in disadvantaged communities and in natural disaster conditions.

\section{Food Security Problem}

Forest resources were bases of food security in many communities. One common use of the forest resource was for livestock grazing and fodder supply, which contributes to food security directly by producing animal products and indirectly by producing farm manure and drought power for crop production. Donor agencies purposively and strategically advised Nepal government and funded to reduce and control livestock holdings of poor communities to increase forest (Hausler, 1993; Ives \& Merselli, 1989). Pine and other non-fodder species were planted in community pastureland. Livestock holdings have decreased significantly as the policy was implemented (Dhakal et al., 2012). Decreasing livestock holdings reduced farm manure production that reduced crop yields and escalated farm land abandonment (Raut et al., 2012; Khanal \& Watanabe, 2006). The REDD programme of some of the donor agencies (e.g. the Himalayan Community Carbon Project funded by SDC, DFID and FINIDA) have designed to reduce livestock grazing and other uses of products by communities. It destroys socio-ecological systems for food security evolved and sustained in mountain geo-ecological condition for centuries. The food security effect of external intervention is higher in remote and high hill communities where transhumance practices of alpine regions collapsed due to restrictions on mobile animal grazing in the forests, which is essential during winter (snowing) and early spring (Dhakal et al., 2011). Loss of forage in forest also contributed on increasing incidence of wild animals on farm crops. Poor households, particularly with elderly and women, are passive victims of food scarcity.

The institutional change and forest management activities for carbon trading and protected areas based biodiversity conservation are done for forever. The changes create many legal complexities and social disputes in the use for food production activities. For example, forests of pine planted in the pasture of the poor communities have been legally restricted to change into fodder production and grazing forests. This requires a long legal battle to get approved the land use change to food production related activities and involves a huge cost and time to develop production and management facilities. The impact of the external interventions on food security, therefore, will be long lasting.

\section{Climate Change Adaptation Problem}

Mountain communities and forest can be further affected by global climate change. Forest species, structure and age compositions are decreased in most of community forests (Shrestha et al., 2012), and more critical in donor supported districts. It requires changes on forest management practices to increase their capacities adaptive to the climate change. It requires increasing diversities in stand composition, structure and age of the forest to enhance resilience (Amato et al., 2011). Biodiversity conservation also requires creating heterogeneity in forest habitat conditions, maintaining functional diversity and reducing the conversion of diverse natural forests to reduced-species (Thompson et al., 2009). It requires heavy management operation and reformation of the forest to increase adaptive capacity to climate change under existing condition. The changes on forest management conflicts with the REDD policy requirement of maintaining baseline forest carbon level. After many years of study Amato et al. (2011) demonstrated clear tradeoffs between the achievement of mitigation and adaptation objectives from forest management. Contrary to the facts the international agencies (e.g. DFID, SDC and FINIDA-refer Table 2) introduced REDD policy for enhancing forest biodiversities and adaptive capacity of forest and communities. The REDD forestry practices are intended to manage the forest in an intact natural condition which promotes aggressive or invasive species, 
leads forest to homogeneity condition, and reduces resources for multipurpose use. It is too early to observe the impacts of the program but it most likely increases vulnerability of both communities and ecosystems systems based on small size of forest. The agencies are also destroying traditional forestry practices and creating new institutional barriers which affect management and utilization of forest resources for adaption to climate change.

\section{The Marginalization of Poor People and Indigenous Communities}

Growing numbers of studies have shown that external intervention in common property management further marginalizes poor people. The community forest management activities introduced by external agencies abolished traditional systems of producing non-timber forest products and directed the promotion of log based forest management (Uprety et al., 2011). Log production requires a longer period and suppresses the growth of many non-timber species underneath the trees (e.g., grasses for livestock and medicinal plans for income generation) and reduces the production of stakes and poles valuable for agricultural. Fodder or grazing was the major means of forest benefit for many households in the old management regime (Maharjan et al., 2003) but it has decreased dramatically in most forests (Dhakal et al., 2011). The reduction in supply of non-timber products also reduced economic activity in the communities that would otherwise benefit poor households that have poor access to off-community or other high returning employment activities. Under the community forest policy, households are allowed to use logs only for home consumption, not for sale by individuals. Poor people consume much lower amounts of timber because of the poorer capacity of the household to use it than rich households. Some community user groups sell the timber in markets at lower than the production cost (a loss of high opportunity benefit), which benefits the elite of urban areas at the expense of the poor people. Fifty per cent of the income from timber sales outside the community goes to District Forest Development Fund, which has been used mostly at the district forest official's discretion. The rest of the income goes to community funds where powerful households indirectly get the lion's share of the benefit.

Current payment for ecosystem services (PES) schemes in both forest and water sectors are not functioning in a true market mechanism. Payments are also not based on an assessment of environment outputs and economic cost/benefit. They are based on discretion, interest and the policy of the implementing agencies. For example, Makawanpur District Council receives 12 percent benefit from the hydropower company and its 20 percent goes to the communities of Kulekhani watershed PES scheme. A study reported that the total annual income for the watershed communities was RS 60,000 (about US \$600) for conservation of over 62,000 ha of forest by over 9000 households (Khatri, 2011). It can be imagined that the foregone benefit for the households from changing the community land management was many folds higher. Alternative management would most probably result in a much better level of the watershed conservation services. Interestingly, the households affected from the PES program, however, are silent against their marginalization which is a common case in community level work due to elites' pressure.

Some policy analysts (e.g. Strassburge et al., 2012) suggest that poor people should leave their forest use to get out of the poverty trap. However, Lam and Paul (2013) study showed that people displaced from the forest conservation suffered due to isolation from their original communities. The declaration of Langtang National Park in Nepal, for instance, reduced local people's access to subsistence forest resources and forced them to find alternative ways of life. Many young girls from the park-affected communities migrated to India and became involved in prostitution because they possessed very low levels of educational, financial and social capital to find other better ways of life. The effects of the external interventions are greater on indigenous ethnic groups that traditionally depended more on multipurpose forest resources and held smaller sized productive private land than other ethnic groups (Vinding \& Kampbel, 2012). Another affected group is women, who take responsibility of households and bear the burden of forest resource scarcity and resultant misery much more than men in the communities.

People in forest development support organizations, international aid agencies and profession have talked much about inclusive development and forestry governance and related to current affaire of political institutional development. In practice they have contributed in developing the institutions which have reduce access to and control over the local forest resources.

\section{Property Rights and Development Barriers}

According to Census 2011, the population growth is negative in 31 out of 75 districts in the country. It has highly increased in other districts and this puts excessive pressure on the environment. The districts with negative population growth have low economic activity and excessive uses of forest resources for conservation. One growing challenge of development is to balance the pressure on environmental resources by managing the population. Rural households cannot manage their way of life on less than 0.5 ha alone because of the changing way of life, which needs income to afford food and development services. Appropriate management of the forest resources could increase means of livelihoods and provide incentives to live in their original communities. Studies have shown that many community forests still have adequate capacity to produce forest products and services and keep people employed under alternative managements (Dhakal et al., 2007).

However, the community pasturelands converted into pine forest under the external advices and supports (financial and technical), for instance, now cannot be managed for fodder production and poverty alleviation because of growing legal and social complexities (Dhakal et al., 2011). Local people have lost their de facto property rights on and access to the forests developed in protected areas. The people have been displaced from their centuries old living place (Vinding \& Kampbel, 2012). It is not only national law but also international law hinders in changing the management of the forests used in protected areas into community oriented management. Moreover, both rich and poor nations are going to be bounded in managing public forests for enhancing carbon sink and tackling global climate change under new phase of the international policy (The REDD Desk, 2012). The policy will further constrain the poor communities to manage their forests currently under REDD for other local uses and benefits. The forestry institutions and forest management induced by external intervention create many complex problems. They are highly likely 
to be too costly to reform in future. In essence the forestlands are being locked which creates barriers for other activities of economic development.

\section{Abuses on Local Communities, Civil Societies and Institutions}

Almost all forestry development agencies have cited socioeconomic problems of local communities to justify rational of their programme activities, and get funding and working approvals. They used poor households in forest protection and conservation programmes but provided little remuneration. They used social pressures (e.g. use environmental media propaganda and approach through local elites) to influence ordinary people and manage the forest resources for achieving best interests and benefit of the external agencies. Most of the agencies know the negative impacts of their interventions on policies and supports at communities through research reports and community work experiences but they have continued funding and implementing further regressive programmes (e.g., the current REDD forestry programme, the multi-stakeholders project and the new protected area development programme) with repeating the false promises of benefiting the poor communities. The alternative forest management practices proven to benefit local people and environmental are little practiced.

The agencies advised and funded to manage the community forest for increasing timber supplies of urban users and offsetting carbon produced by affluent societies. They did even risky and unethical experimentation of the REDD policy on forests that are the sources of the livelihoods means of barely surviving poor people. The policy influenced communities' decisions and dictated forest management rules for restricting collection of the daily needed forest products and services and for planting trees in the remaining forest spaces used in producing daily needed non-timber products(Uprety et al., 2011; Khadka, 2012). Traditional farming practices (e.g., shifting cultivation and collection of woody green products and fodder including livestock grazing of the tribal groups and other communities have been officially declared a criminal practice. The restrictions on uses of forest products and services to sustain livelihoods compel many households to abandon their business and farm, and in some cases, leave the community for good. The forest based people are blamed for encroaching on environmentally sensitive land and using forest resources (Rasul \& Thapa, 2003) but it is ignored the fact that the territories of the indigenous people are encroached by government policies and activities of other societies; and the communities are squeezed in marginal lands, and forced them to grow crop in sensitive lands and shorter rotation. The agencies have, therefore, disrespected and challenged livelihoods and way of lives indigenous people barely living on the forest resources.

International aid and support agencies have also impaired the advocatory capability and position of civilian societies (NGOs, forest user groups and other organizations) on forestry issues. The Federation of Community Forestry User Group Nepal (FECOFUN), for instance, a body assumed to represent the interests and act to safeguard the interests and wills of community forest users, has been influenced and used in businesses by donors and other agencies from its establishment. Its constitution was prepared by representative of donor agencies and has directed the FECOFUN to contributing to the conservation of community forest rather than representing and safeguarding the interests and wills of community forest user groups. In addition, from the beginning it has intensively worked in the guidance and business of donor and other external agencies and mediated and influenced by the agencies to such a degree that its members cannot express strong disagreement on any issue on the policy or programme of donors even if they know these are against forest communities. External agencies have involved FECOFUN, for example, directly in the REDD project, which contains many policies and activities highly contrary or conflicting to resource rights and livelihoods of forest users. The external agencies, therefore, involved FECOFUN in project implementation with the objective of neutralizing potential confrontational position of forest user groups and escaping from the blame of any wrong doing. This is an abuse of community institution to manage the local forest resources for meeting interest of the international agencies.

The disadvantaged households are forced to co-operate the forestry programmes of vested agencies. Instead of voicing against inappropriate forest management and their marginalization, the victims say that they do not want to be barriers of development and innovation, and place them odd in community. Rather they are compelled to co-operate (Shrestha \& McManus, 2008). They are in fact trapped in the "value of forest development and innovation" tactically socially constructed by national and international elites. This situation can be termed as an oppressed state of the people. Some new generations of the victim people may understand the abuses and oppressive actions of the external agencies. They may have contemptuous against the people working in the agencies, and ego feelings to take revenge. But compounding of legal and social complexities leaves them little room to bring the justice.

\section{The Problem in International Forestry Policy: A Kaleidoscopic Case}

The inappropriate international intervention is not typically limited to Nepal. but also find in other developing countries. For example, Community Forestry International (a California based INGO run by the US university professors) has advised and prepared a REDD project in Khasi tribal communities, a vulnerable social group in India (Project Idea Note, 2011). The project is funded by the USAID and certified by Plan Vivo Foundation (a Scottish-based INGO). The tribal community has eighty-five percent land areas under forest. Its private landholding size is average 0.25 ha per household which is insufficient to produce enough food for family consumption alone. The funding and supporting agencies have planned and practiced to replace local fodder based livestock (cattle) system by imported grain based livestock (poultry and pig) system. According to the REDD project agreement the community people must comply that "(iii) Cattle if reared, should be of superior breed and stall-fed with cattle feed procured from outside" (Project Idea Note, 2011: p. 16). In advising the communities and funding in the project, the resourceful agencies have ignored potential socioeconomic problems of the vulnerable communities and risk of losing socio-ecological systems and services (e.g. forest resource based agrobiodiversity) evolved and sustained hundreds of year of community civilization. It is very interesting about saliency of high profiled and knowledgeable international agencies (e.g. FAO, UNEA and CIFOR) which could effectively communicate the critical problems in international level and influence on international policy decisions. The 
agencies, for example FAO and RECOFT rather recognize the above work as an innovation (Vicker et al., 2012).

The international policy problem can be considered a kaleidoscopic case and explained by multiple schools of thought. Some schools of thought are as follows.

a) Proponents of the western hegemony school of thought argue that most of the western values and practices are incompatible with conditions and needs of forest based communities in developing countries, and in many cases environmentally unsustainable or unfriendly. However, international policies and practices of forestry are founded on the western world's institutions, values, social preferences and practices which are routed through education of forestry professionals or decision makers, the origin place of development support organizations, main source of funding, languages, people's expertise and pro-western preference in influential job positions. The values, ideas and practices of the non- western world are filtered and suppressed through different institutional routes. People with challenging views are excluded in opportunities and supporters of western values and views are rewarded. The pervasiveness of the western hegemony has made national professionals powerless to understand and protect the quality of local institutions and practices and real needs of disadvantaged citizen. Therefore forestry resources traditionally managed for local environment and socioeconomic benefits are hampered by increasing western influences in developing countries.

b) Scholars of the institutional school of thought argue that the community unfriendly activities and marginalization are outcomes of bad governance and weak institutions of the government of host countries. Many invisible hands involved in working on international policies and influencing decisions in their own favour. Under the financial and symbolic (political and language) influences of aid agencies the governments in developing countries recognize any capacity level of people from developed countries as experts, and allowed to be influential in policy and other management decisions. The developing countries are favorite working destinations for the people particularly with poor technical capacity, learners or interest in relaxed lives of developing countries. The experts mostly provide poor quality of technical services. If international aid agencies hire any expert from developing countries they hire to the people who have characteristics of working in their interest and benefits instead of host countries. Due to weak institutional capacity the governments of developing countries could not defend against the wrong doing and protect national interest and local needs.

c) The proponents of the behavioral school of thought argue that explaining the emerging local problems of forestry is the professional areas of expertise and responsibility of forest scientists, academicians, practitioners and related environmentalists. Now the professional people have not have worked scientifically and played their professional roles because of over-influences of environment media and activists of global environmental issue. Many of them have benefited from working in the interest and benefit of powerful societies or countries or on global issue. The others have lost their constructive thinking and scientific visioning abilities in relation to local community needs and broader environmental problems. The wrong doings of the people have been little challenged by other professional groups, civil societies and intellectuals because of technical complexities in environmental issues. Local communities have been victim of the bad professional services or roles of the people influential on forestry decision making.

d) Proponents of the neocolonial school of thought argue that developed countries, purposely and strategically introduced the new forestry institutions and management practices to lock the forestland resources used in food production and destroy livestock farming in developing countries. The developed countries have influenced forest policies in developing countries various ways such as offering funds on the forestry programs of their interest, influencing international environment conservation policies, employing their people at influential level in international organizations and using diplomatic pressures. The restriction on land uses in developing countries increases future market of agricultural products for developed countries which have hold vastly privatized lands and well developed agricultural technologies and institutions. This land use strategy provides the developed countries opportunities to balance import of industrial products from developing countries as well as influence on world development policy by controlling food. The control on the uses of forests and the production of livestock in the poor communities also reduces global greenhouse gas emission, which would relieve the pressure on emission intensive businesses in the developed countries.

e) The argument of proponents of the gangster (mafiasm) school of thought differs from the proponents of the neocolonial school of thought. According to the school of thought, an influential "gang” of business people (called think tanks, academicians, experts and consultants) have socially tactically constructed the forest policies and values in the world, and sold to influential political actors including governments in developed countries who are desperate of ideas and policy solutions to cool down public outcry for environmental management in home, and keep their symbolic and political existence in overseas. The mafia developed the ideas and constructed new social values on forest to maximize their own benefit. They do little care negative impacts to societies and environment. Same natures of people find in other all over the world and most of them have got opportunity to work and influence in policies and practices at international, regional, national and local levels. The followers of the mastermind gang have propagated and implemented the forest policies ideas twisted interpretation of real forestry phenomena and practices, and are paid by developed countries. Other people hopped on their bandwagon. The forests are managed according to the strategies of the mafia group and poor communities became victim of the management.

Most probably all of the factors can have played some roles on the emerging problems of forestry policies and practices in developing countries but at different degrees.

\section{Conclusion}

The purpose of this study is to explain whether international interventions and supports on forest management in developing countries result in positive socioeconomic and environmental outcomes at local communities. The finding shows that international interventions to manage developing countries' forests for global environmental conservation can make over-influence on forestry policies and practices and spoil indigenous locally 
adaptable forestry systems evolved and practiced in hundreds of years. The forestry institutions and management practices oriented for global environmental interest result in tradeoffs of production of other environmental services mostly of local importance. They are more likely to lock opportunities of multipurpose management and uses of the forest, worsened water yield, reduced local food security and local knowledge, and hampered local economic activities. The management can also reduce habitat diversities for forest based species and resource supplies for sustaining agro-biodiversities. Poor people are also most likely to be suffered when community forests are managed for global interest, particularly extreme environmental conservation purpose such as offsetting greenhouse gas emission and protected area based biodiversity conservation. The international interventions can also make local forestry institutions and practices too costly to change for improving benefit level to the forest based communities and local environmental systems. The interventions lock local forest resources and institutions in the position to benefit distance users for long term. The findings reveal that the supports of international forestry agencies can benefit global or powerful societies. However, the agencies are less likely to work for the benefit of local community and environment. They care little about the strategic development position of institutionally weak countries.

Interestingly, the policy interventions and technical supports of international agencies are found technically wrong or poorly based on science, though forestry professionals, environmental policy analysts and academicians of high profile organizations are involved in the policy formation and implementation processes. The work benefitted national elites and other distance users (urban households in the country and affluent societies in overseas) at the expenses of poor communities and local environment. The forestry case reveals that many people working in high profile international organizations are not trustworthy or have poor level of professional ethic.

The forestry problems have been almost impossible to be resolved particularly working at the initiation of community because they reached to a very complex level. Furthermore, it has been an international strategy to continue the locally bad forest policies and practices for international benefit. National level forest policy decisions are controlled or influenced by conservative and corrupt forestry people. Influential international agencies have provided incentive to national elites in promoting the policies and practices. Awareness also works little to alleviate the problem because the aid agencies and influential people in forestry profession are well aware that their actions further marginalized poor communities and degraded local environment. A social movement of like-minded people at both international and national levels, however, may make some changes. Triggering of such movement requires breeding of a heinous feeling with a significant numbers of people working in forestry-related profession with the sense that they deceived local communities and worked against local environment and the poor people in order to address interest of affluent society and other distant users.

\section{Acknowledgements}

Most international organizations (e.g. World Bank, FAO, ICIMOD, SDC, DFID, USAID, NORAD, IUCN, WWF and FINIDA) have claimed that they have advocated, advised and funded the government and civil societies to change forest management policy and practices for improving local environment, promoting sustainable local practices for mountain development and benefiting socially disadvantaged communities. However, their interventions have made the rural poor and local environment worse. The effects of the problems are pervasive and critical in both short and long terms. The influential agencies have ignored the issues and rather promoted further worse policies and practices. The communities have been fooled, deceived, oppressed and exploited by national professional elites and international agencies under the veil of forest development and environment conservation. The issues are poorly explained and shared in popular open access literatures. The fact motivated author in explaining and sharing the realities. He would also like to thank Dr Narendra Chanda, Department of Forest Nepal, for providing data about REDD program.

\section{REFERENCES}

Amato, A., Bradford, J., Fraver, S., \& Palik, B. (2011). Forest management for mitigation and adaptation to climate change: Insights from long-term silviculture experiments. Forest Ecology and Management, 262, 803-816. http://dx.doi.org/10.1016/j.foreco.2011.05.014

Basnet, K. (2003). Transboundary biodiversity conservation initiative: An example from Nepal. Journal of Sustainable Forestry, 17, 205226. http://dx.doi.org/10.1300/J091v17n01_12

Bruijnzeel, L. (2004). Hydrological functions of tropical forests: Not seeing the soil for the trees? Agriculture, Ecosystems and Environment, 104, 185-228. http://dx.doi.org/10.1016/j.agee.2004.01.015

CBS (2008). Environmental Statistics of Nepal 2008. Kathmandu: Central Bureau of Statistics.

CBS (2011). Preliminary results of National Population Census 2011. Kathmandu: Central Bureau of Statistics.

Christensen, M., \& Heilmann, J. (2009). Forest biodiversity gradients and the human impact in Annapurna Conservation Area, Nepal. Biodiversity and Conservation, 18, 2205-2221. http://dx.doi.org/10.1007/s10531-009-9583-9

Dhakal, B., Bigsby H., \& Cullen, R. (2012). Socioeconomic impacts of public forest policies on heterogeneous agricultural households. Environmental and Resource Economics, 53, 73-95. http://dx.doi.org/10.1007/s10640-012-9548-4

Dhakal, B., Bigsby, H., \& Cullen, R. (2007). The link between community forestry policies, and poverty and unemployment in rural Nepal. Mountain Research \& Development, 27, 32-39.

Dhakal, B., Bigsby, H., \& Cullen, R. (2011). Forests for food security and livelihood sustainability: Policy problems and opportunities for small farmers in Nepal. Journal of Sustainable Agriculture, 35, 86115. http://dx.doi.org/10.1080/10440046.2011.530903

Dong, S., Lassoie, J., Yan, Z., Sharma, E., Shrestha, K., \& Pariyar, D. (2007). Indigenous rangeland resource management in the mountainous areas of northern Nepal: A case study from the Rasuwa District. The Rangeland Journal, 29, 149-160. http://dx.doi.org/10.1071/RJ07033

Douglas, J., \& Simula, M. (2010). The future of the world's forests: Ideas vs ideologies. Dordrecht: Springer Netherlands. http://dx.doi.org/10.1007/978-90-481-9582-4

Eckholm, E. (1975). The deterioration of mountain environments. Ecological stress in the highlands of Asia, Latin America, and Africa takes a mounting social toll. Science, 189, 764-770. http://dx.doi.org/10.1126/science.189.4205.764

Edmonds, E. (2003). Development assistance and the construction of government-initiated community institutions. Economic Development and Cultural Change, 51, 897-930. http://dx.doi.org/10.1086/377160

FAO (1996). Shivapuri management plan: Technical recommendations and policy design for the protection and development of the Shivapuri Areas including the Participatory Management of Shivapuri Resources (GCP/NEP/048/NOR) Kathmandu. Rome: FAO. 
FAO (2010). Global Forest Resources Assessment 2010-Nepal. Country Report, Rome: FAO.

Folke, C., Colding, J., \& Berkes, F. (2003). Synthesis: Building resilience and adaptive capacity in social-ecological systems. In: F. Berkes, J. Colding, \& C. Folke (Eds.), Navigating social-ecological systems (pp. 352-387). Cambridge: Cambridge University Press.

Gartaula, H.N., Visser, L., \& Niehof, A. (2012). Socio-cultural dispositions and wellbeing of the women left behind: A case of migrant households in Nepal. Social Indicators Research, 108, 401-420. http://dx.doi.org/10.1007/s11205-011-9883-9

GON (2012). REDD+ in Nepal: A brief introduction. Kathmandu: Government of Nepal Ministry of Forests \& Soil Conservation REDD-Forestry and Climate Change Cell.

Harrop, S.R. (2007). Traditional agricultural landscapes as protected areas in international law and policy. Agriculture, Ecosystems \& Environment, 121, 296-307.

http://dx.doi.org/10.1016/j.agee.2006.12.020

Hobley, M. (1996). Participatory forestry: The process of change in India and Nepal. Londo: Rural Development Forestry Network, Overseas Development Institute.

Hrabovszky, J., \& Miyan, K. (1987). Population growth and land use in Nepal "The Great Turnabout". Mountain Research and Development, 7, 364-270. http://dx.doi.org/10.2307/3673203

IUCN (2006). Policy brief 3: The costs and benefits of conserving Shivapuri National Park Catchment, Nepal. Colombo: IUCN.

Ives, J., \& Messerli, B. (1989). The Himalayan dilemma reconciling development and conservation. London \& New York: The United Nations University and Routledge.

Kala, C., \& Shrivastava, R. (2004). Successional changes in Himalayan Alpine Vegetation: Two decades after removal of livestock grazing. Weed Technology, 18, 1210-1212. http://dx.doi.org/10.1614/0890-037X(2004)018[1210:SCIHAV]2.0.C $\underline{\mathrm{O} ; 2}$

Kanel, K., Shrestha, K., Tuladhar, A., \& Regmi, M. (2012). A study on the demand and supply of wood products in different regions of Nepal. Kathmandu: REDD-Forestry Climate Change Cell Babarmahal.

Kapos, V., et al. (2012). Impacts of forest and land management on biodiversity and carbon. In J. A. Parrotta, C. Wildburger, \& S. Mansourian (Eds.), Understanding relationships between biodiversity, carbon, forests and people: The key to achieving REDD+ objectives (pp. 53-80). A Global Assessment Report, IUFRO World Series Vol 31, Vienna: IUFRO.

Karky, B. S., Karki, S., Rana, E. B., \& Kotru, R. (2012). Innovative intervention and strategies in Nepal for implementing REDD+ at the community level. Redefining Paradigms of Sustainable Development in South Asia, SDPI and SDC.

Karsenty, A., \& Ongolo, S. (2011). Can "fragile states" decide to reduce their deforestation? The inappropriate use of the theory of incentives with respect to the REDD mechanism. Forest Policy and Economics, 18, 38-45. http://dx.doi.org/10.1016/j.forpol.2011.05.006

Khadka, M., Karki, S., \& Chapagain, A. (2012). Gender consideration in the REDD+ payment piloting in Nepal: Maintaining or challenging unequal gender power relations? The Bhutan+10 International Conference on Gender and Sustainable Mountain Development in a Changing World, Thimphu, 15-19 October 2012.

Khanal, K. (2002). Under utilization in community forest management: A case study from Lalitpur District. Banko Janakari, 12, 26-32.

Khanal, N., \& Watanabe, T. (2006). Abandonment of agricultural land and its consequences: A case study in the Sikles Area, Gandaki Basin, Nepal Himalaya. Mountain Research and Development, 26, 32-40. http://dx.doi.org/10.1659/0276-4741(2006)026[0032:AOALAI]2.0.C $\mathrm{O} ; 2$

Kharel, et al. (2005). Performance characteristics of the yak in Nepal and its crosses with mountain cattle.

http://agtr.ilri.cgiar.org/Casestudy/yak/Yak.htm
Khatri, D. B. (2011). Payments for ecosystem services in Kulekhani Watershed of Nepal: An institutional analysis of mechanisms for sharing hydroelectricity revenue. 13th International Association of Study of Commons Conference at Hyderabad, Hyderabad, 10-14 January 2011, 1-60.

Lam, L.M., \& Paul, S. (2013). Displacement and erosion of informal risk-sharing: Evidence from Nepal. World Development, in Press.

MPFS (1988). Master Plan for the Forestry Sector Nepal (MPFS) Main Report Ministry of Forests and Soil Conservation. Kathmandu: Government of Nepal.

Pandit, B., \& Kumar, C. (2010). Factors influencing the integration of non-timber forest products into field crop cultivation: A case study from eastern Nepal. Journal of Sustainable Forestry, 29, 671-695. http://dx.doi.org/10.1080/10549811003741599

Phelps, J., Friess, D. A., \& Webb, E. L. (2012). Win-win REDD+ approaches belie carbon-biodiversity trade-offs. Biological Conservation, 154, 53-60.

Project Idea Note (PIN) (2011). Project idea note for the Umiam Sub-watershed REDD+ Project. East Khasi Hills District Meghalaya, India. Plan Vivo. http://www.planvivo.org/wp-content/uploads/Khasi-Hills-Communit y-REDD-ProjectIdeanote-May13EM.pdf

Rasul, G., \& Thapa, G. B. (2003). Shifting Cultivation in the Mountains of South and Southeast Asia: Regional Patterns and Factors Influencing the Change. Land Degradation \& Development, 14, 495-508. http://dx.doi.org/10.1002/ldr.570

Raut, N., \& Sitaula, B. K. (2012). Assessment of fertilizer policy, farmers' perceptions and implications for future agricultural development in Nepal. Sustainable Agriculture Research, 1, 188-200. http://dx.doi.org/10.5539/sar.v1n2p188

Robinson, R., \& Sutherland, W. (2002). Post-war changes in arable farming and biodiversity in Great Britain. Journal of Applied Ecology, 39, 157-176. http://dx.doi.org/10.1046/j.1365-2664.2002.00695.x

Rokaya, M, Münzbergová, Z., \& Timsina, B. (2010). Ethnobotanical study of medicinal plants from the Humla district of western Nepal. Journal of Ethnopharmacology, 185, 485-504. http://dx.doi.org/10.1016/j.jep.2010.05.036

Shrestha, K., \& McManus P. (2008). The politics of community participation in natural resource management: Lessons from community forestry in Nepal. Australian Forestry, 71, 135-146. http://dx.doi.org/10.1080/00049158.2008.10676280

Shrestha, U., Shrestha, B., \& Shrestha, S. (2010). Biodiversity conservation in community forests of Nepal: Rhetoric and reality. International Journal of Biodiversity and Conservation, 2, 98-104

Strassburg, B., et al. (2012). Social and economic considerations relevant to REDD+. In J. Parrotta, C. Wildburger, \& S. Mansourian (Eds.), Understanding relationships between biodiversity, carbon, forests and people: The key to achieving REDD+ objectives. A Global Assessment Report, IUFRO World Series Vol.31, Vienna: IUFRO.

Thompson, I., Mackey, B., McNulty, S., \& Mosseler, A. (2009). Forest Resilience, Biodiversity, and Climate Change. A synthesis of the biodiversity/resilience/stability relationship in forest ecosystems. Technical Series No. 43, Montreal: Secretariat of the Convention on Biological Diversity.

Uprety, D., Luitel, H., \& Bhandari, K. (2011). REDD+ and conflict: A case study of the REDD + projects in Nepal. Kathmandu: The Center for People and Forest (RECOFTC) and ForestAction Nepal.

Vicker, B., Trines, E., \& Pohnan, E. (2012). Community guidelines for assessing forestry volunteer carbon market. Bangkok: Food and Agriculture Organization of the United Nations Regional Office for Asia and The Pacific.

Vinding, D., \& Kampbel, E. (2012). Indigenous women workers: With case studies from Bangladesh, Nepal and the Americas. Geneva: International Labour Organization. 